\title{
Evaluation of Dredging Operations for Tigris River within Baghdad, Iraq
}

\author{
Ammar Ali1,2, Qusay Al-Suhail ${ }^{3}$, Nadhir Al-Ansari'1, Sven Knutsson'1 \\ ${ }^{1}$ Department of Civil, Environmental and Natural Resources Engineering, Lulea University of Technology, Lulea, \\ Sweden \\ ${ }^{2}$ College of Engineering, Baghdad University, Baghdad, Iraq \\ ${ }^{3}$ College of Science, Baghdad University, Baghdad, Iraq \\ Email: ammar.ali@Itu.se, nadhir.alansari@Itu.se, sven.knutsson@ltu.se, ammali_75@yahoo.com, \\ quab65@yahoo.com
}

Received 23 January 2014; revised 21 February 2014; accepted 11 March 2014

Copyright (C) 2014 by authors and Scientific Research Publishing Inc.

This work is licensed under the Creative Commons Attribution International License (CC BY).

http://creativecommons.org/licenses/by/4.0/

(c) ()

\begin{abstract}
River Tigris divides Baghdad, capital of Iraq, in two parts. The reach of the river within Baghdad is about $60 \mathrm{~km}$ long. Many islands and bars are obstructing the flow of the river within Baghdad. To overcome this problem, dredging operations started along most of Tigris River inside Baghdad City to remove many islands and side bars, which reduced the flooding capacity and the efficiency of water intakes. An examination for the dredging plan under process and two proposed additional plans was performed using the Hydrologic Engineering Centers River Analysis System software (HEC-RAS) for a $50 \mathrm{~km}$ long river reach to investigate whether they can recover the designed flooding capacity of the river or just improving it. Calibration and verification processes were implemented in the model using observed water levels at Sarai Baghdad gauging station and along the last $15 \mathrm{~km}$ of the river reach. Comparisons of computed water levels were conducted with those of previous studies and historical data. Some improvement of flood capacity was achieved based on the recorded data of the last three decades. Cautions about the water intakes should be considered to maintain their function with the expected drop in water level due to dredging operations.
\end{abstract}

\section{Keywords}

Baghdad; Dredging; Flooding Capacity; Tigris River

\section{Introduction}

Baghdad City is the capital of Iraq. The city is bisected into two parts from the north to the southeast by Tigris

How to cite this paper: Ali, A., et al. (2014) Evaluation of Dredging Operations for Tigris River within Baghdad, Iraq. Journal of Water Resource and Protection, 6, 202-213. http://dx.doi.org/10.4236/jwarp.2014.64026 
River for a distance of $60 \mathrm{~km}, 50 \mathrm{~km}$ of which are located within the urban areas, and the rest is in rural parts (Figure 1).

Tigris River reach within Baghdad has compound meanders, single channel and alluvial plain characteristics. According to the meandering characteristics, Tigris River can be divided into two parts. The northern part, starts from Al-Muthana Bridge north of the city and ends at Sarai Baghdad gauging station in the centre of the city. This part is characterized by a series of small meanders. While the southern part, which is characterized by its large meanders, starts from Sarai Baghdad gauging station and ends at the confluence between Tigris and Diyala rivers to the south of the city (Figure 1 ).

The banks of the river within the northern part and about $49 \%$ of the southern part were been protected by stones and cement mortar. Thirteen bridges were been installed along the reach; three of which were damaged partially and reconstructed during the last 22 years [1].

Water flow of Tigris River entering Iraq was decreased dramatically during the last two decades due to the huge water projects constructed across the river in Turkey and Iran [2] [3]. The recent dry climatic period in Iraq and the region increased the severity of the problem. As a result, the flow of Tigris River at Baghdad dropped from $927 \mathrm{~m}^{3} / \mathrm{s}$ as the average monthly discharge (1960-1999) to about $520 \mathrm{~m}^{3} / \mathrm{s}(2000-2012)$ [4].

Tigris River has many growing islands, side and point bars along its reach inside Baghdad City (surrounded by red borders in Figure 1). The obstacles in the river course can be briefly summarized by the presence of 10 islands and 17 side bars. Dimensions, types and distribution of most of these obstacles were discussed in details by Ali [4].

The negative impacts of these obstacles can be classified under two groups. The first is that related to the hydraulic performance of the river. This includes changing of the river cross sections that reduces the flooding capacity of the river, decreasing water depth at the intakes of water pumping stations and approaching the river bed from the intakes mouths, the impossibility of navigation along the whole reach and limitation to discrete zones, threating the banks protection stability at some locations due to deep eroding incisions in the river bed near these protections at the meanders. The second impact is related to the river environment and aesthetic such as increasing the turbidity, growing of reeds, water hyacinth and ceratophyllum demersum at stagnant locations, as well as the disfiguration of aesthetic view over the river and its banks.

An effective rapid action was required to consider preventing this deterioration in the performance of the river. Iraqi Ministry of Water Resources (IMoWR) executed dredging operations at specified locations along the river inside Baghdad to overcome the existing problems where at the end of 2012 a flooding wave of $3000 \mathrm{~m}^{3} / \mathrm{s}$ passed through the river inside Baghdad. This caused inundation of parts of the city where the design flooding capacity of Tigris River was reduced due to the obstacles within the river course [1]. When considering the dredging plan pressing questions arise: Is dredging the more efficient measure to be taken? And how efficient

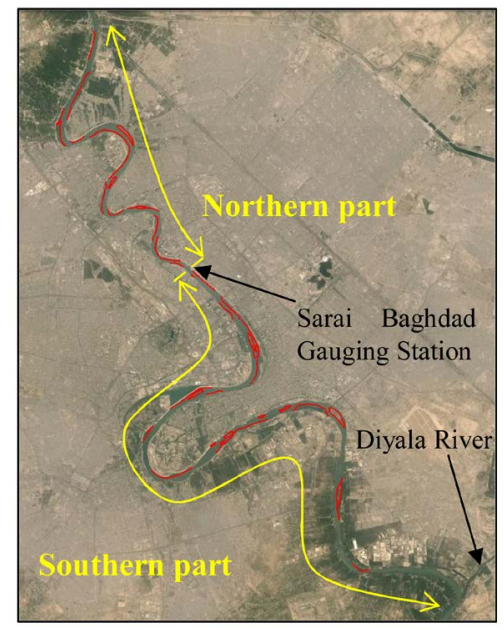

Figure 1. Tigris River inside Baghdad (islands and side bars surround by red borders) (the raw image from Google Earth $\left.^{\circledR}\right)$. 
the dredging operations from the river hydraulic performance point of view? To answer these questions, a simulation hydraulic model was required to investigate the improvements of the flooding capacity of Tigris River along the dredged reach inside Baghdad due to dredging operations at certain locations, as well as determining the associated changes in the hydraulic performance of the river.

In this research, three main questions are to be answered concerning the dredging operations which were executed by IMoWR. Firstly, having these dredging operations executed at certain locations improved the flooding capacity along the whole reach of Tigris River inside Baghdad? If not, then, is there a need for additional measures? Secondly, since the main slope of the river reach changed [1], is there a necessity to recover the design cross section at the dredged locations to get back the original designed flooding capacity? Thirdly, is there a future impact of the dredging operations on the hydraulic performance of the river if there are no other effective measures to consider, which preventing recurrence of forming the same islands or new islands?

\section{Previous Studies and Surveys of Tigris River}

Three surveys were conducted for Tigris River in different occasions. The first was conducted in 1976 by Geohydraulique [5], followed by University of Technology in 1991 [6], and finally by IMoWR in 2008. The first two surveys (1976 and 1991) are related to studies about training of Tigris River to improve its flooding capacity and prevent possible collapses of its banks due to erosions caused by high discharges. The former suggested banks protections to maintain the cross sections of the river during floods depending upon the geometry of the river as a result of the survey conducted at that time. In the later, recommendations were given to the protections details of the banks that were not protected at that time depending upon the geometry of the river in the 1991 survey. Consequently, the design cross sections of Tigris River are represented on the design drawing of the river's banks protection project in the two phases discussed above.

The survey of 2008 showed significant changes in the geometry of Tigris River, as well as significant reduction in the flooding capacity of the river 1).

\section{Dredging Process of Tigris River inside Baghdad City}

IMoWR decided that dredging might be a major treatment process for most of the hydraulic problems in Tigris River. Such kind of work required significant financial and technical potentials where some were not available for IMoWR prior 2008. The main aims set by IMoWR for the dredging operations in Tigris River were:

- Removal of all the sediment deposited on the bed and banks at specified locations along the river to recover the design cross section to maintain the flooding capacity of the river [7].

- Maintaining water intakes and prevent them from clogging.

- Improving the appearance of the river and its banks.

In 2004, IMoWR did some institutional and administrative changes and replaced the company that was specialized in dredging work by an office called "Office of Executing Rivers Dredging Works (OERDW)".

The dredging work was executed at limited locations on the river for the period 2004-2007 using excavators and one dredger at that time. OERDW imported many dredgers and supplementary equipment in 2008. Most of the dredgers are of cutter suction type (Figure 2) and some of the backhoes type (Figure 3). Large staff was trained to execute this operation. The dredging extended over twenty sites along the river as well as purging of ten water intakes (Figure 4).

The work was carried out at some sites and is still in progress at different levels in other sites. In some early dredged sites, especially at water intakes, dredging was repeated due to the accumulation of sediment deposited with time.

Figure 4 shows the locations to be dredged from the main obstacles in the whole northern part of the river reach and about the half of the southern part as planned by OERDW. The remainder of the southern part of the river was not taken into consideration because it has fewer numbers of obstacles and passes through industrial and agricultural areas only.

The areas that were considered in the dredging plan are shown in Figure 5. There were many exceptions in the plan. One of the main obstacles in the northern part (Kura'at Island) which was ignored from the plan due to an investment decision which was taken by the local authorities considering the site as tourist area. The second exception was the biggest island along the river reach (Dura Island) at the middle of the southern part of the river, as well as the side bar just upstream that island (Figure 6). 


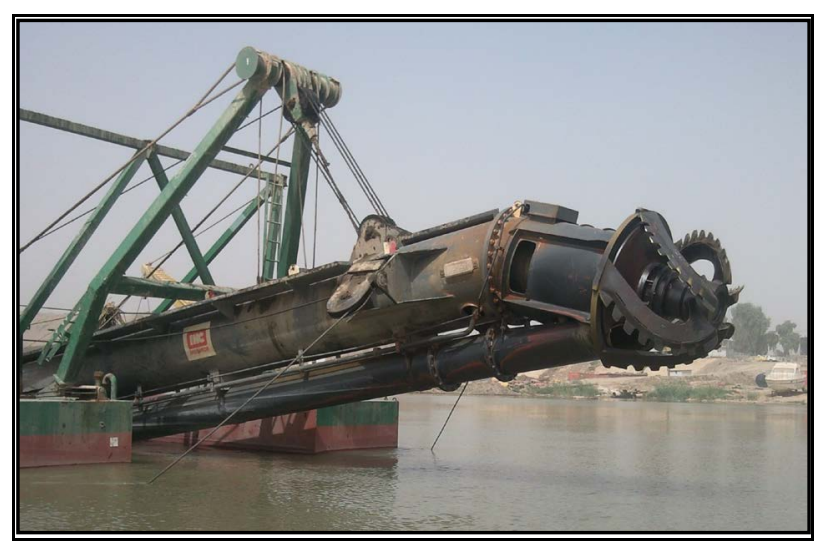

Figure 2. A dredger of type cutter suction working on Tigris River (the photo was taken by the authors).

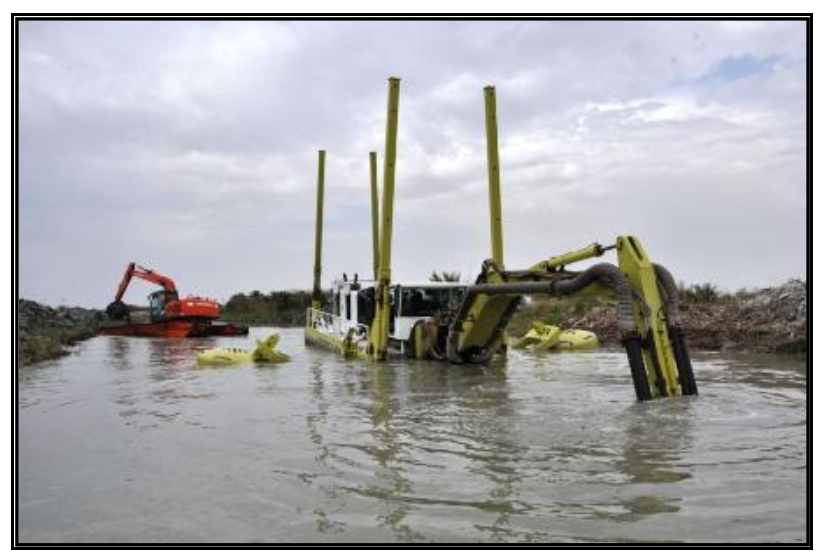

Figure 3. A dredger of type backhoe working on Tigris River (source [8]).

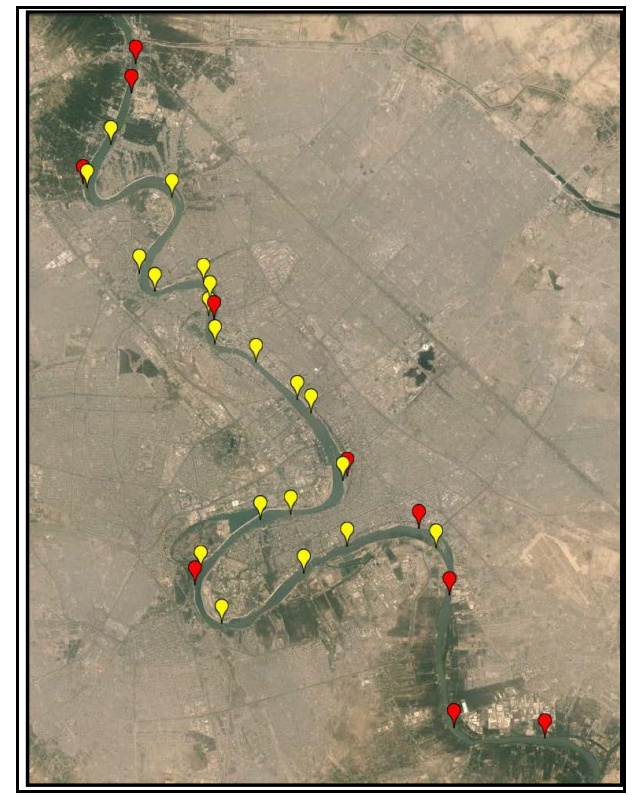

Figure 4. Dredging (yellow) and water intakes (red) sites along Tigris River (the raw image from Google Earth ${ }^{\odot}$ ). 


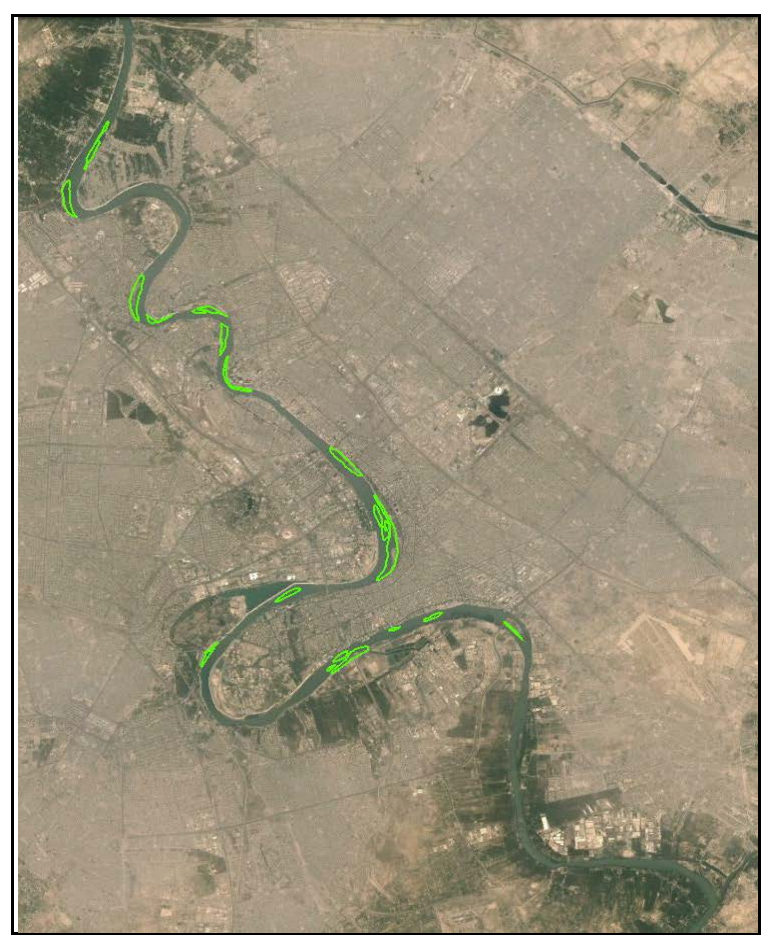

Figure 5. The considered areas in the dredging plan of OERDW [6] (the raw image from Google Earth ${ }^{\circledR}$ ).

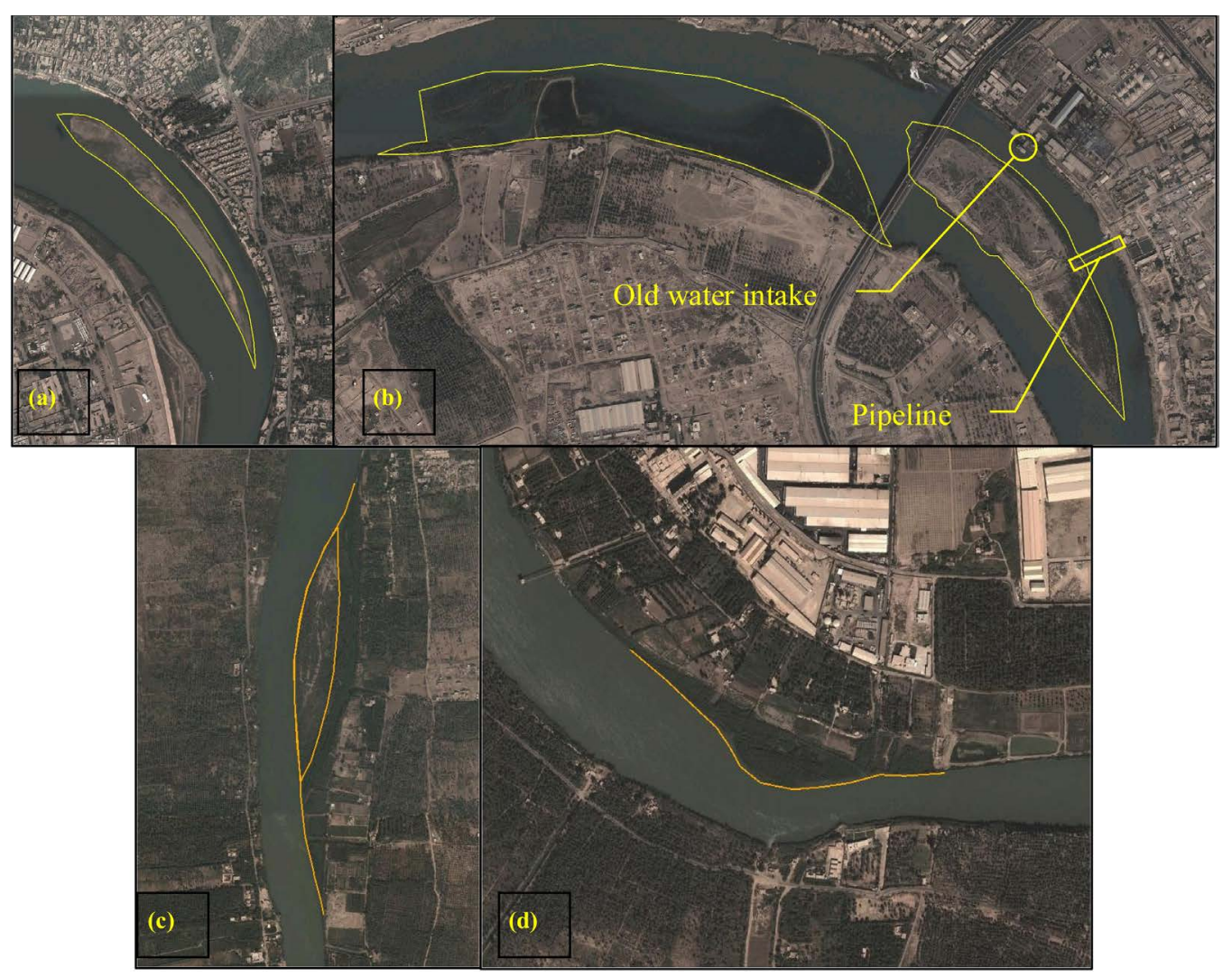

Figure 6. The excepted obstacles from OERDW dredging plan ((a) Kura'at Island; (b) Dura Island and the side bar; (c) Al-Rasheed Camp Island and D. PEPSI Factory Island) (the raw images from Google Earth ${ }^{\odot}$ ). 
The estimated quantities of sediment to be removed were about 3,443,000 $\mathrm{m}^{3}$ depending upon the topography of 2008 surveys and the additional surveys which were conducted by OERDW at the proposed dredging locations at different dates. New sediment depositions after the dredging operations were neglected in the estimations simply because the current rates of erosion and deposition were unknown.

The dimensions and the depths of dredging depended on the experiences of the engineers of OERDW. Sometimes the dredging does not match the dimensions of the design cross sections. This is due to the fact that they believe that dredging will not necessarily brings the geometry of the river to the designed flooding capacity at that location.

In addition to the plan above, two more dredging programs were suggested. The first, is dredging most of the sediment deposition locations, especially within the upper banks depositions and the stacks of the dredged materials, which were originally excluded from OERDW plan along the northern river reach and the first half of the southern river reach as shown in Figure 7.

The suggested locations that have more effect on the flooding capacity are those of the narrowest sections where the high detentions for the flow may occur at their sections which influence water levels upstream during high discharges as that at the suspension bridge and Dura power plant locations (Figure 8). It should be noted that, the suspension bridge was destroyed in 1991 and re-built with two auxiliary bridges of huge number of piles. This represented a source of additional disturbance for the flow which was associated with deposition of sediment. One of these auxiliary bridges was removed during 2011 and 2012 while the second remains (Figure 8(a)). On the other hand, Dura power plant location (Figure 8(b)) is the narrowest part of the river reach where its width doesn't exceed $80 \mathrm{~m}$. Furthermore, it is located at sharp meander with lined outer bank.

The estimated quantities of the sediment suggested to be removed according to this plan were about 1,330,000 $\mathrm{m}^{3}$.

The second additional program included the dredging of Dura Island (see Figure 6(b)) in the southern part of the river reach. This is due to the fact that it takes about $59 \%$ of the river width and bisects a large meander. In addition, the outer arm of the meander has some obstacles represented by an old intake for a power plant on the left shore and small truss bridge to pass pipes of the new intake from the island to the power plant. The sediment quantity that was suggested to be removed was about $610,000 \mathrm{~m}^{3}$.

\section{Methods and Techniques}

Fifty kilometres of Tigris River reach which are located within the urban areas was considered in this work starting from Al-Muthana Bridge to the north and ending at the confluence of Tigris-Diyala Rivers to the southeast. Cross sections of 2008 surveys of Tigris River were used to represent the geometry of the river. The average spacing between cross sections is about $250 \mathrm{~m}$.

The Hydrologic Engineering Centers River Analysis System (HEC-RAS) software was used to perform one-dimensional simulation for a range of steady flows in Tigris River and obtain the associated water surface profiles. Calibration is an important step for such kind of mathematical models to get valid results. For this purpose, 59 water surface observations along the last $15 \mathrm{~km}$ of the river reach were used to calibrate Manning's roughness coefficient along the river. These observations were measured for $400 \mathrm{~m}^{3} / \mathrm{s}$ discharge which represents low discharge for the river. The upstream boundary condition was the same discharge for the measured water levels. While the downstream boundary condition was stage-discharge rating curves for Tigris River downstream the confluence. The contribution of Diyala River was represented by $5 \mathrm{~m}^{3} / \mathrm{s}$ lateral inflow which represents the average annual flow. The best calibration was achieved by the mean of minimum Root Mean Square Errors (RMSE) between the observed data and computed water surface profile for several iterations of finding suitable Manning's $n$ values for the main channel and the flood plain. These iterations culminated by obtaining Manning's " $n$ " of 0.0285 for the main channel and 0.042 for the flood plain with RMSE equalled to $0.026 \mathrm{~m}$ (Figure 9).

Verification process is the next step on the way of modelling. A set of recorded discharges with their water levels at Sarai Baghdad gauging station during the last 12 years were used in the verification process. These discharges $\left(400,500,800,1100\right.$ and $\left.1300 \mathrm{~m}^{3} / \mathrm{s}\right)$ were classified from low to moderate discharges according to the historical records. Good agreement was achieved between observed water levels for the recorded data and those computed by HEC-RAS for the same discharges. The RMSE for verification was $0.046 \mathrm{~m}$ at Sarai Baghdad (Figure 9). 


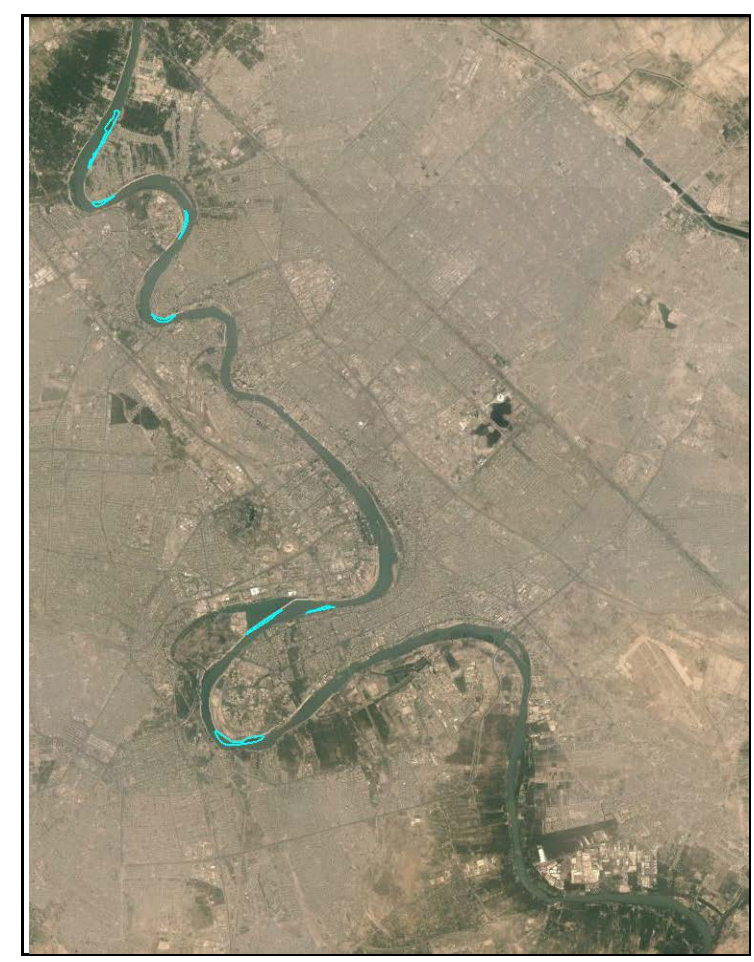

Figure 7. The suggested areas for dredging according to the first additional plan (the raw image from Google Earth $^{\odot}$ ).

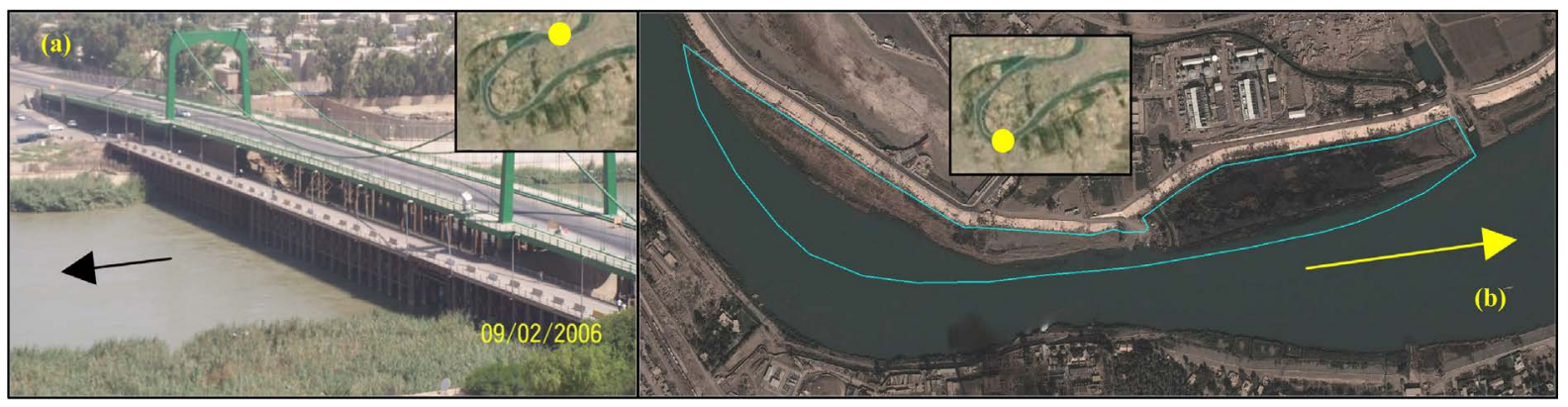

Figure 8. The narrowest sections of Tigris River reach ((a) The suspension bridge; (b) Dura power plant) (the raw images from Google Earth $^{\odot}$ ).

\section{Dredging Simulation Results}

Several modifications for the cross sections were implemented to consider the changes of the river geometry due to the dredging operations. Some changes in the roughness coefficient at the locations of the removed obstacles were considered so that the effect of the additional roughness due to the presence of the obstacles was removed. The first modification taken into consideration was the dimensions of the dredging program that was considered by the decision makers in OERDW, whether they were executed on the field or planned to be executed. The suggested two additional programs mentioned above were also implemented based upon the modification of OERDW plan. The modified geometries were supplied to HEC-RAS program with a range of steady flows to obtain the associated water surface profiles. This is to find out whether the dredging program recovered the design flooding capacity of the river, exceeded the required limits or needs additional dredging.

Water surface profiles were computed along the river reach for a range of discharges $(400,500,800,1100$, 1300, 1500, 2500, 2700, 3500 and $4000 \mathrm{~m}^{3} / \mathrm{s}$ ) in Tigris River. This range of the selected discharges was examined for the same reach in previous works carried out by Geohydraulique [5], University of Technology [6] 


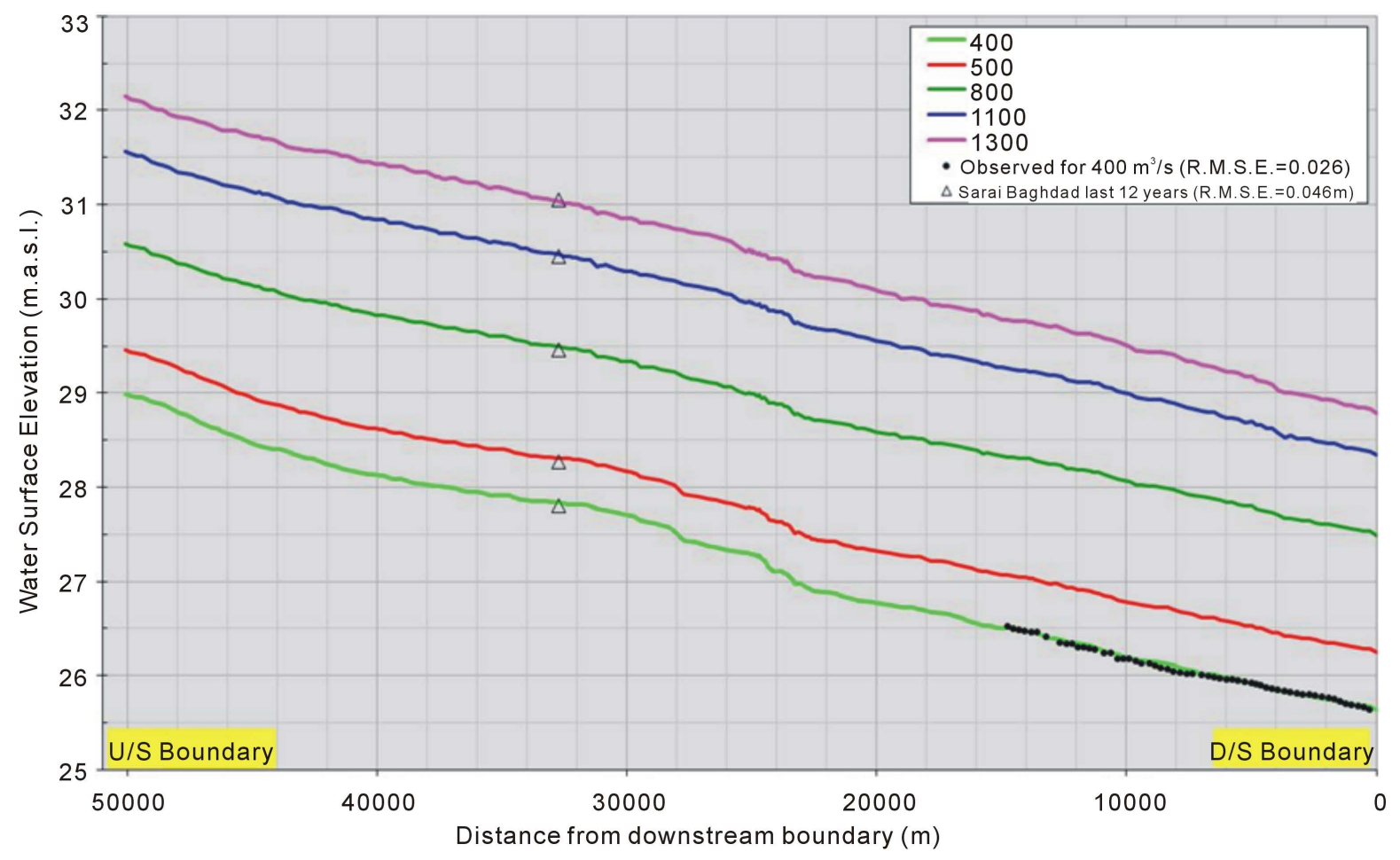

Figure 9. Water surface profiles of tigris river for calibration and verification processes.

and Ali et al. [1]. Therefore, it was preferable to exam the same discharges with the new river geometries. There was no need to change the downstream rating curve because it was valid in the calibration and verification processes as well as it is far away from the dredging sites.

Water surface profiles related to selected discharges $\left(400,800,1100,2500\right.$ and $\left.3500 \mathrm{~m}^{3} / \mathrm{s}\right)$ were plotted for all dredging plans as well as the pre-dredging condition in Figure 10. The selection of these discharges was based on different criteria, where the predominant discharge in Tigris River now a day is around $400 \mathrm{~m}^{3} / \mathrm{s}$, while a discharge of $800 \mathrm{~m}^{3} / \mathrm{s}$ represents the moderate discharge for the river during the last decade. The University of Technology [6] concentrated on two discharges, 1100 and $3500 \mathrm{~m}^{3} / \mathrm{s}$, assuming that the first one is the operational discharge for the river and the second is the critical indication for the flooding capacity of the river and it was also the significant discharge in evaluating the flooding capacity for 2008 [1]. The discharge $2500 \mathrm{~m}^{3} / \mathrm{s}$ was chosen for bridging the gap between 1100 and $3500 \mathrm{~m}^{3} / \mathrm{s}$ discharges.

The drop in water levels was clear for the low discharges (400, 800 and $1100 \mathrm{~m}^{3} / \mathrm{s}$ ) along the river reach that was included in the dredging program and the profiles are mostly identical for all plans. That drop will affect the operation levels of the water intakes especially along the northern part of the reach, so more caution should be taken to keep the water intakes functional. The effect of the second additional plan seems to be very limited and took place only at the location of Dura Island and its vicinity. The differences between the first two dredging programs are restricted to the upper portions of the river cross sections, while the second additional dredging program was concerned with the removal of the island.

During high flooding discharges (2500 and $3500 \mathrm{~m}^{3} / \mathrm{s}$ ) there are convergences between the profiles of the dredging plans and the pre-dredging condition (Figure 10). It should be mentioned, however, there is a very little advantage for the first additional plan which indicates that the effect of the banks deposition is more significant on the flooding capacity of the river. Computed water levels at Sarai Baghdad gauging station were compared with those obtained from the previous works [1] [5] [6] and with a summary of historical records for the last four decades as shown in Figure 11. From this figure, the following conclusions were noticed:

-1970s: Many high peaks were recognized. They ranged between 2230 and $3890 \mathrm{~m}^{3} / \mathrm{s}$, but the maximum was $4480 \mathrm{~m}^{3} / \mathrm{s}$ in 1971. This suggests that the patterns of erosion and deposition were not stable due to the oscillation between the amount of sediment brought by floods and flashing process. 

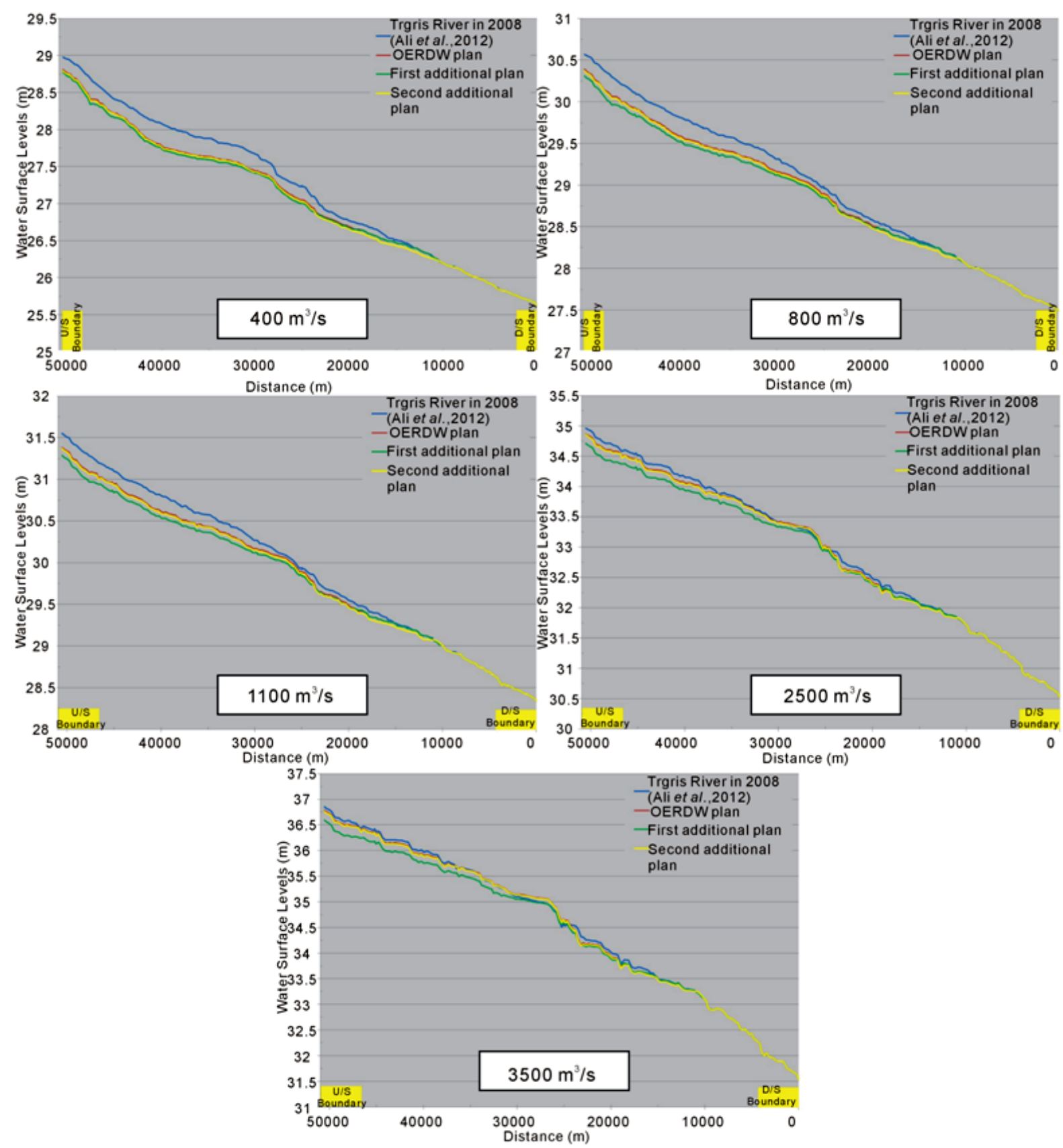

Figure 10. Water surface profiles related to selected discharges for all dredging plans and pre-dredging condition.

The recorded water levels were higher than the results of the dredging plans for 400,500 and $800 \mathrm{~m}^{3} / \mathrm{s} \mathrm{dis-}$ charges and very close to 1100,1300 and $1500 \mathrm{~m}^{3} / \mathrm{s}$ discharges and significantly lower for higher discharges. For this reason, the dredging plans cannot achieve the water levels for the flooding cases of the 1970s, because the river at that period was not protected at the banks and had milder bed slope than it is now [1].

-1980s: The available water levels are only restricted for the periods between October 1987-September 1988 and October-December 1989. The maximum peak recorded was $3060 \mathrm{~m}^{3} / \mathrm{s}$ at water level $35.03 \mathrm{~m}$ in April 1988. Other peaks (894 to $1998 \mathrm{~m}^{3} / \mathrm{s}$ ) were lower than the previous. The effect of head water dams that were constructed during that decade was clear on the values of the peaks. The available records were close to the results of the dredging plans for the 500, 800 and $1100 \mathrm{~m}^{3} / \mathrm{s}$ discharges, while they were higher for the 2500 and 2700 $\mathrm{m}^{3} / \mathrm{s}$ discharges. No records of water levels are available for the rest of the discharges in range. 


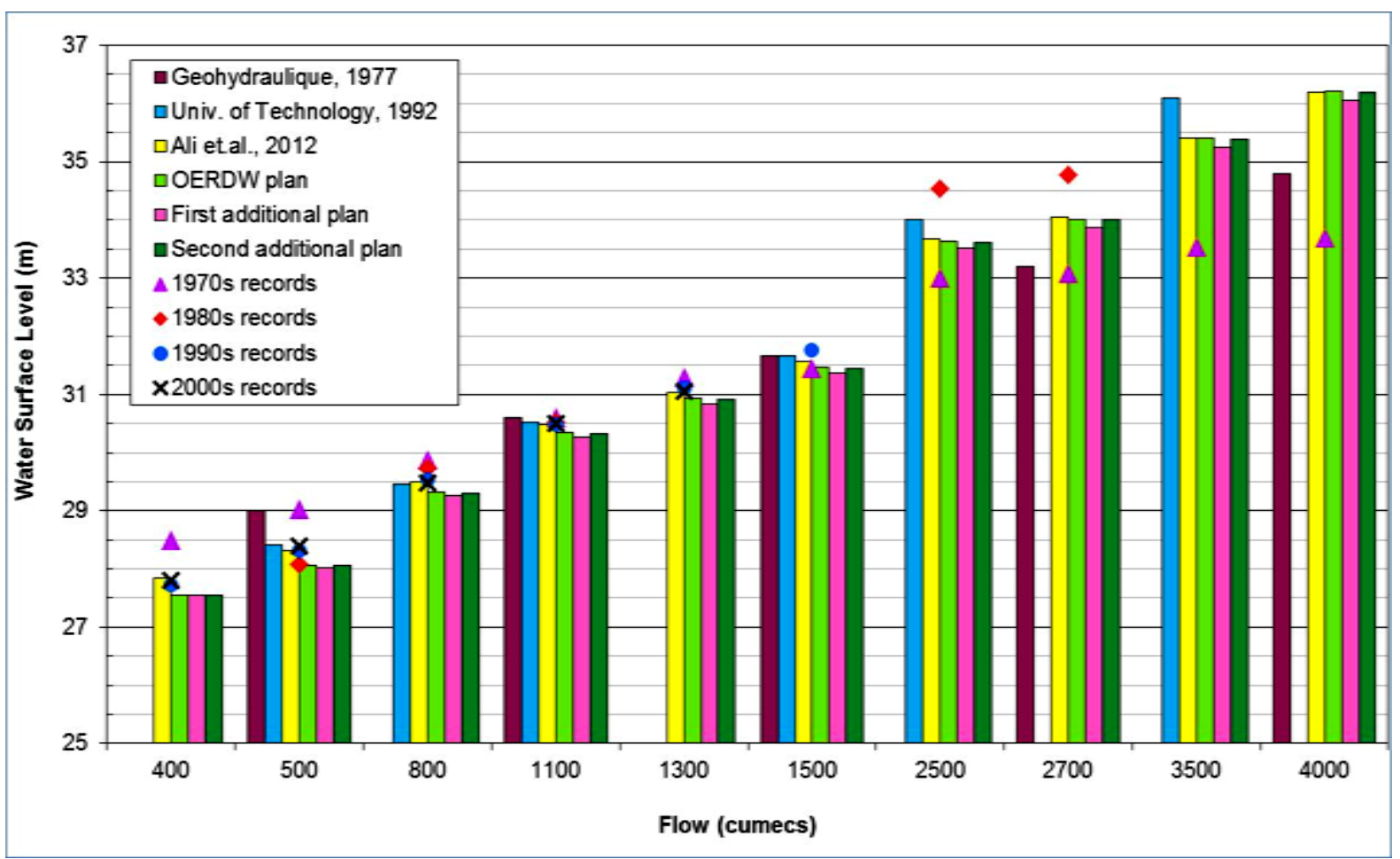

Figure 11. Computed water levels at Sarai Baghdad gauging station for all dredging plans with the results of previous studies and the observations of the last four decades.

-1990s: The peaks were between 990 and $1825 \mathrm{~m}^{3} / \mathrm{s}$. The recorded water levels were very close to those of the previous decade. The river seemed more tranquil. The results of the dredging plans are closer to the recoded water levels which covered the discharges $400-1500 \mathrm{~m}^{3} / \mathrm{s}$ from the examined range.

-2000s: The range of peaks in those records were the lowest $\left(515-970 \mathrm{~m}^{3} / \mathrm{s}\right)$ relative to the last four decades. The maximum peak did not exceed $1315 \mathrm{~m}^{3} / \mathrm{s}$ in 2004 . The recoded water levels were very close to those of 1990s but they covered a narrower range $\left(400-1300 \mathrm{~m}^{3} / \mathrm{s}\right)$ of the examined discharges.

It is axiomatically to know that since the river bed geometry changes, and then the velocity distribution will change also. What we don't know whether this change will be positive or negative from erosion and sedimentation points of view. To solve this query, a two-dimensional hydrodynamic model is required to be used for the new river geometry to find the velocity distribution. In addition, the texture of the river bed material and the transported sediment are to be investigated. Generally speaking, since the river has these huge quantities of sediment deposited on its bed and banks as mentioned earlier which were coupled with decrease in water discharge, it is very logical to assume that the velocity reduction will lead to more sediment deposition.

A comparison was made to the changes in the longitudinal average velocities along the river reach. This comparison includes the velocities before implementing dredging operations, after implementing dredging operations and for the suggested two plans (Figure 12). This figure shows the negative and positive differences. When the average velocity of the river increases due to dredging with respect to the pre-dredging condition then, this was considered positive. This might keep the deposition rate as it is. Negative differences (which are the most dominant along the river reach) however, are exactly opposite to the first case. Repetition of dredging at some locations on the river can enhance this concept.

\section{Conclusions}

The conclusions about dredging operations carried out by OERDW on Tigris River within Baghdad after 2008 can be summarized as follows:

1) For low discharges of 400, 800 and $1100 \mathrm{~m}^{3} / \mathrm{s}$, there will be clear drop in water levels along those dredged parts of the river. 

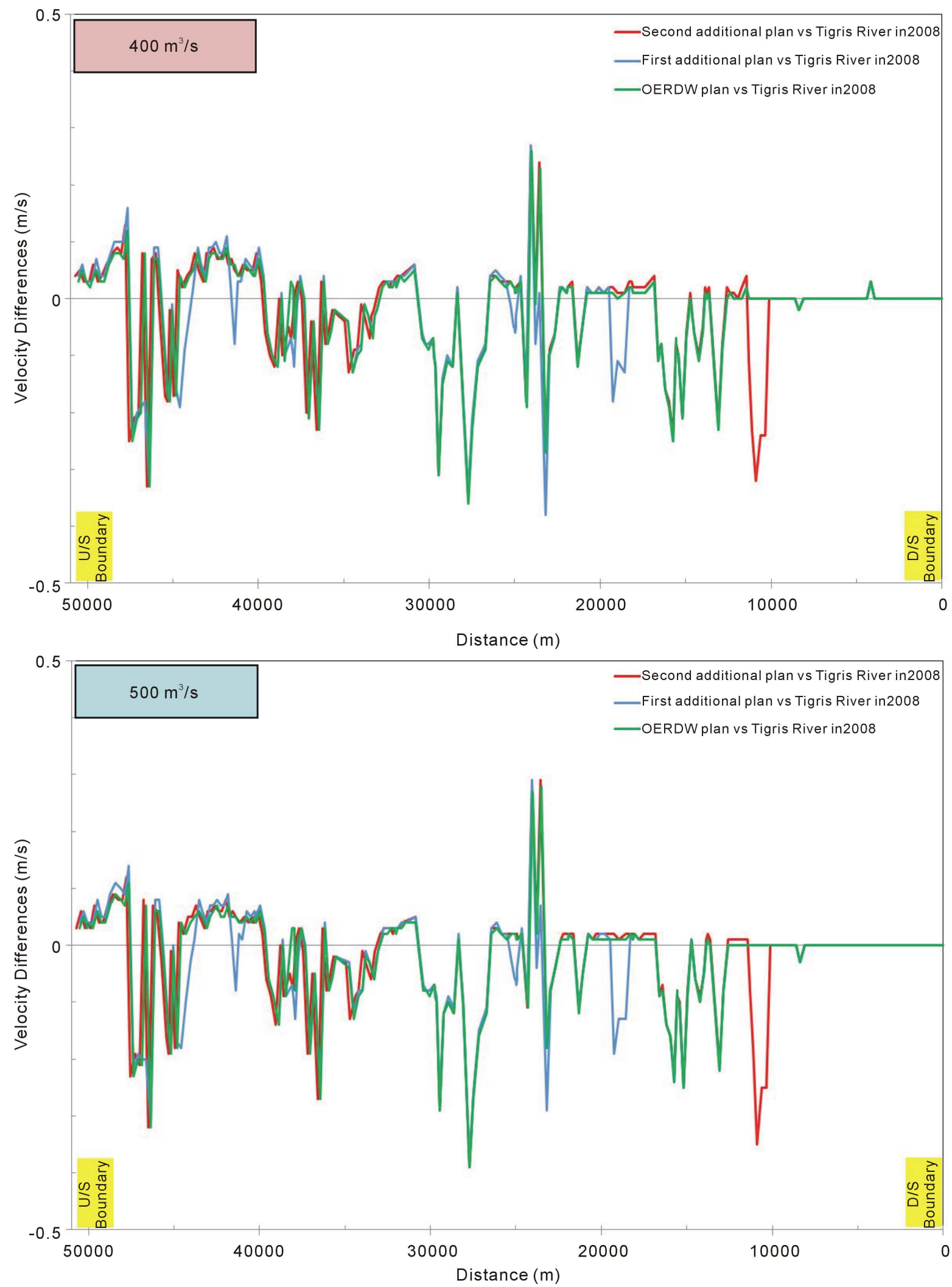

Figure 12. Velocity differences along the river reach between the average velocities of pre-dredging condition and the results of the dredging plans for the low discharges. 
2) The differences between the dredging programs or plans are concentrated on the upper banks depositions which are reflected on the water surface profiles for low discharges where they were almost identical for all dredging plans.

3) For high discharges (the flooding cases) 2500 and $3500 \mathrm{~m}^{3} / \mathrm{s}$, the water surface profiles are very converge even with the pre-dredging condition.

4) In flooding cases, the first additional plan gave lower water profiles. This is an advantage for the first additional plan which can satisfy flooding cases.

5) The effect of the second additional plan was limited to the location of Dura Island and nearby areas.

6) The application of the dredging plans can recover the water levels at Sarai Baghdad to those of 1970s for the discharges range 1100 to $1500 \mathrm{~m}^{3} / \mathrm{s}$, but not for higher discharges.

7) The dredging plans can reduce Sarai Baghdad water levels for less than those of 1980s for the range discharges 2500 to $2700 \mathrm{~m}^{3} / \mathrm{s}$.

8) The expected water levels at Sarai Baghdad will be closer to what they were during the last three decades for low discharges.

9) Some caution should be taken to keep the water intakes functional due to the expected drop in water levels, especially along the northern part of the river reach.

10) Dredging plans along the dredged part of the river reach will be associated with reductions in longitudinal velocities and more sedimentation is expected to take place at these locations.

11) The estimated quantities of sediment to be removed by OERDW plan are about $3,443,000 \mathrm{~m}^{3}$. Fewer amounts of sediment quantities for the first additional plan were estimated (about 1,330,000 $\mathrm{m}^{3}$ ) and lesser for the second one (about $610,000 \mathrm{~m}^{3}$ ).

12) The new sediment that will be deposited during the execution of any one of the dredging plans was not considered because the current rates of erosion and deposition are unknown.

\section{Acknowledgements}

The research presented has been financially supported by Luleå University of Technology, Sweden and by "Swedish Hydropower Centre-SVC" established by the Swedish Energy Agency, Elforsk and Svenska Kraftnät together with Luleå University of Technology, The Royal Institute of Technology, Chalmers University of Technology and Uppsala University. Their support is highly appreciated. The Iraqi Ministry of Water Resources gratefully helped the authors to conduct this research.

\section{References}

[1] Ali, A.A., Al-Ansari, N.A. and Knutsson, S. (2012) Morphology of Tigris River within Baghdad City. Journal of Hydrology and Earth System Sciences, 16, 3783-3790. http://dx.doi.org/10.5194/hess-16-3783-2012

[2] Al-Ansari, N.A. and Knutsson, S. (2011) Toward Prudent Management of Water Resources in Iraq. Journal of Advanced Science and Engineering Research, 1, 53-67.

[3] Al-Ansari, N.A. (2013) Management of Water Resources in Iraq: Perspectives and Prognoses. J. Engineering, 5, 667-684.

[4] Ali, A.A. (2013) Morphology of Tigris River inside Baghdad City. Licentiate Thesis, Lulea University of Technology, Lulea.

[5] Geohydraulique (1977) Tigris River Training Project within Baghdad City. Report Submitted to the Iraqi Ministry of Irrigation, Paris.

[6] University of Technology (1992) Training of Tigris River inside Baghdad City. Report Submitted to the Iraqi Ministry of Agriculture and Irrigation, Baghdad.

[7] IMoWR (Iraqi Ministry of Water Resources) (2013) The Aims of the Dredging of Tigris River, 2013. http://www.mowr.gov.iq/?q=node/571 (in Arabic)

[8] OERDW (Office of Executing Rivers Dredging Works) (2013) http://erdw.mowr.gov.iq/ (in Arabic) 